\title{
Analisis Pengelolaan Sarana dan Prasarana Pembelajaran
}

\author{
Ria Ramdhiani* \\ Prodi Pendidikan Guru PAUD, Fakultas Tarbiyah dan Keguruan, \\ Universitas Islam Bandung, Indonesia. \\ *riaramdhianis@yahoo.com
}

\begin{abstract}
Educational facilities really determine the success of education, because in education facilities and infrastructure play an important role in the learning process. Facilities and infrastructure affect the learning process, thus determining effective and efficient learning. With this research, the researcher will examine the management of facilities and infrastructure inincluding, planning of facilities and infrastructure, procurement of facilities and infrastructure, use of facilities and infrastructure, and maintenance of facilities and infrastructure. This study aims to obtain an overview of the management of facilities and infrastructure in. The approach and method used in this study uses a qualitative descriptive method. Data collection techniques uses interviews, observation, and case study regarding the management of facilities and infrastructure in .The data obtained during the study are described in the form of words to draw conclusions. Based on the data analysis that has been carried out, it can be concluded that: planning for facilities and infrastructure is carried out by looking at the needs then adjusted to the land and funds owned, procurement of facilities and infrastructure is carried out by buying or borrowing and funds obtained from foundations, BOP, and donations from parents of students, use is carried out by analyzing needs, developments and according to the learning theme. maintenance at is carried out routinely, on a scale, and in an emergency.
\end{abstract}

Keywords: facilities, infrastructure, management of facilities and infrastructure.

Abstrak. Fasilitas pendidikan sangat menentukan suatu keberhasilan pendidikan, karena sarana prasarana sangat berperan penting dalam proses pembelajaran. Sarana dan prasarana berpengaruh terhadap proses pembelajaran, sehingga menentukan pembelajaran yang berjalan efektif dan efisen. Dengan adanya penelitian ini maka peneliti akan mengkaji tentang pengelolaan sarana dan prasarana meliputi, perencanaan sarana dan prasarana, pengadaan sarana dan prasarana, penggunaan sarana dan prasarana, dan pemeliharaan sarana dan prasarana. Penelitian ini bertujuan memperoleh gambaran pengelolaan sarana dan prasarana di lembaga PAUD. Pendekatan dan metode yang digunakan dalam penelitian ini menggunakan metode kualitatif pendekatan studi kasus. Teknik pengumpulan data menggunakan wawancara, observasi, dan studi kasus mengenai pengelolaan sarana dan prasarana di lembaga PAUD. Data yang diperoleh selama penelitian diuraikan dalam bentuk kata-kata untuk ditarik kesimpulanya. Berdasarkan analisis data yang telah dilakukan dapat disimpulkan yaitu: perencanaan sarana dan prasarana dilakukan dengan melihat kebutuhan kemudian disesuaikan dengan lahan dan dana yang dimiliki, pengadaan sarana dan prasarana dilakukan dengan cara membeli atau meminjam dan dana yang diperoleh dari yayasan, BOP, dan sumbangan orang tua murid, penggunaan dilakukan dengan cara menganalisis kebutuhan, perkembangan dan disesuaikan dengan tema pembelajaran, pemeliharaan di lembaga PAUD dilakukan secara rutin, berskala, dan darurat.

Kata Kunci: sarana, prasarana, pengelolaan sarana dan prasarana. 


\section{A. Pendahuluan}

Pendidikan anak usia dini bertujuan untuk membantu meningkatkan pertumbuhan dan perkembangan anak dengan seluruh aspek perkembangan seperti, agama dan moral, fisikmotorik, bahasa, sosial emosional, dan seni. Untuk mencapai perkembangan anak dibutuhkannya sarana dan prasarana sebagai proses perkembangan anak, agar dapat menstimulasi berkembang dengan baik. Menurut Inawati (2014), sarana pendidikan yaitu alat atau keperluan yang digunakan untuk menunjang proses pendidikan, peralatan sarana untuk proses pembelajaran yang diperlukan yaitu, meja, kursi, bangunan, alat-alat dan media untuk mengajar. Sementara itu prasarana pendidikan yaitu alat penunjang utama untuk proses pendidikan seperti, lahan, ruang kelas, halaman sekolah, kebun dan tempat yang menunjang proses pembelajaran.

Dengan adanya sarana dan prasarana membantu proses pembelajaran, sehingga menentukan keberhasilan dalam pembelajaran. Dalam proses pembelajaran diperlukannya alat dan media pembelajaran yang diperlukan untuk membantu pembelajaran. Contohnya pembelajaran yang tidak efektif seperti, ketika proses pembelajaran kelas yang akan digunakan bocor, atau tidak terawat. Oleh sebab itu, suatu lembaga membutuhkan pengelolaan sarana prasarana

Pengelolaan sarana dan prasarana sangat berpengaruh untuk belajar dan mengajar. Suatu keberhasilan pembelajaran akan berhasil, jika pengelolaan sarana dan prasarananya memadai dan mendukung. Menurut Ni'matul (2017), Sarana dan prasarana sekolah berpengaruh terhadap perkembangan anak sehingga bisa mengagalkan proses belajar dan mengajar. Kenyataanya dalam setiap sekolah masih banyak sarana dan prasarana yang tidak sesuai standar yang ada didalam kemendikbud sehingga pengelolaannya sarana dan prasarananya belum optimal.

Sarana dan prasarana menjadi sumber daya pendidikan yang berpengaruh terhadap belajar mengajar sehingga pentingnya mengelola sarana prasarana dengan baik. Manajemen sarana dan prasarana dengan pengelolaan sarana dan prasarana bagian yang tidak bisa dipisahkan. Contohnya, lahan, halaman, bangunan atau gedung, perlengkapan ape dalam, dan ape luar. Sarana prasarana pendidikan patut dikembangkan terus menerus, didalam mengembangkan sararana prasarana dibutuhkanya pengelolaan sarana dan prasarana yang baik. Pengelolaan sarana dan prasarana sangat berpengaruh kepada kegiatan belajar dan mengajar.

Menurut Suyadi (2017), ada empat pengelolaan sarana dan prasarana yaitu, perencanaan, pengadaan, penggunaan serta pemeliharaan. Oleh karena itu sarana dan prasarana membutuhkan pengelolaan yang baik dan mendukung dikarenakan sarana dan prasarana merupakan sumber daya pendidikan yang berpengaruh terhadap proses pembelajaran.

Berdasarkan hasil dari penelitian Rahmiga (2019), mengemukakan tentang pengelolaan sarana dan prasarana ialah rendahnya sarana dan prasarana di Indonesia sehingga banyak sarana dan prasarana yang kurang memadai dalam menunjang proses pembelajaran. Contohnya, lahan yang sempit, jumlah bangku yang tidak sesuai dengan kapasitas siswa, dan kelas yang sering kebanjiran akibat bocor.

Menurut Yuliani (2011) mengemukakan tentang pengelolaan sarana dan prasarana yaitu terdapat beberapa sekolah yang masih belum berhasil dalam pengelolaan sarana dan prasarana, sehingga menyebabkan kegagalan dalam proses belajar mengajar. Dengan adanya pengelolaan sarana dan prasarana akan membantu keberhasilan proses pembelajaran antara guru dan siswa.

Menurut Jannah (2020), menyatakan bahwa pengelolaan sarana dan prasrana ialah terdapat beberapa kondisi dilapangan masih banyak sekolah yang belum mempunyai sarana dan prasarana yang sesuai dengan aturan pemerintah.

Berdasarkan latar belakang yang telah diuraikan, maka perumusan masalah dalam penelitian ini ialah: "Bagaimana pengelolaan sarana dan parsarana pembelajaran?" Berikutnya, tujuan dalam penelitian ini sebagai berikut.

1. Untuk mengidentifikasi dokumen perencanaan sarana dan prasarana di lembaga PAUD

2. Untuk menemukan sistem pengadaan sarana dan prasarana di lembaga PAUD

3. Untuk mengidentifikasi penggunaan sarana dan prasarana di lembaga PAUD 
4. Untuk menemukan berbagai upaya dalam pemeliharaan sarana dan prasarana di lembaga PAUD

\section{B. Metodologi Penelitian}

Metode yang digunakan oleh peneliti ialah metode kualitatif dengan pendekatan studi kasus. Data dan sumber data dalam penelitian ini didapat dari data primer. Dalam pemilihan sumber data, peneliti melibatkan orang-orang yang terlibat langsung dalam pengelolaan sarana dan prasarana. Data yang akan dipaparkan yaitu, keadaan sekolah (sarana dan prasarana), dan pengelolaan sarana dan prasarana. Sumber data diambil dengan data primer dan sekunder. Sumber data primer yaitu data yang langsung dikumpulkan oleh peneliti di lapangan secara langsung. Sedangkan sumber data sekunder yaitu peneliti mengambil data dengan cara tidak langsung, seperti melihat laporan, data-data dan dokumentasi.

Untuk memperoleh informasi peneliti menggunakan metode pengumpulan data dengan cara observasi, wawancara, dan dokumentasi. Observasi yang digunakan oleh peneliti yaitu observasi non partisipan, dimana peneliti mengunjungi tempat penelitian untuk mengamati, mencatat, dan menganalisis sarana dan prasarana yang ada. Peneliti mengamati keberadaan lahan, keberadaan ruangan, kondisi lahan, keberadaan perabotan, kondisi perabotan, keberadaan permainan, dan kondisi permainan. Selanjutnya peneliti melakukan wawancara secara terstuktur dimana peneliti memberikan pertanyan-pertanyaan mendalam kepada narasumber.

Tujuan dari wawancara ini ialah untuk mendapat informasi yang tepat mengenai pengelolaan sarana dan prasarana dari kepala sekolah, dan guru-guru. Tahap terakhir dalam metode pengumpulan data peneliti melakukan dokumentasi baik secara tertulis atau data-data, secara tergambar, dan secara terekam.

Data yang dikumpulkan kemudian diolah lalu dianalisis dengan langkah-langkah sebagai berikut:

1. Reduksi data

Seluruh data yang diperoleh peneliti melalui hasil dari wawancara, observasi dan dokumentasi. Setelah mendapatkan data-data yang diperlukan, peneliti memilah-milih data yang dianggap penting dalam pengelolaan sarana dan prasarana. Setelah data yang dipilih oleh peneliti, kemudian peneliti melakukan analisis data pengelolaan sarana dan prasarana.

2. Penyadian data,

Dari seluruh data yang telah dipilih, peneliti menganalisis data pengelolaan sarana dan prasarana. Kemudian peneliti menyiapkan data dan menguraikan informasi-informasi dengan singkat. Adapun peneliti menguraikan informasi data melalui teks narasi, bagan atau table.

3. Kesimpulan atau Verifikasi data.

Seluruh data yang telah didapat, peneliti memilah-milih data dan menganalisis data yang telah didapat. Selanjutnya peneliti menguraikan dan mencatat data yang telah dipilih dan dianalisis, kemudian peneliti membuat kesimpulan dan melakukan pengecekan kembali data-data yang telah didapat

Data yang telah dikumpulkan kemudian dilakukan pemeriksaan dan keabsahanya dengan cara trianggulasi, baik trianggulasi sumber dan teknik.

\section{Hasil Penelitian dan Pembahasan}

\section{Pengelolaan Sarana dan Prasarana}

Menurut Rahminawati (2016), Sarana dan prasarana yang dimiliki sekolah harus dimanfaatkan dan dikelola untuk berjalannya proses pembelajaran di sekolah. Pengelolaan tersebut ditujukan supata dalam penggunaan sarana dan prasarana sekolah dapat berjalan dengan efektif dan efisien. Pengeloaan sarana dan prasarana termasuk kegiatan yang sangat penting di sekolah, dikarenakan adanya pengelolaan sarana dan prasarana dapat mendungkung suksesnya proses belajar mengajar di sekolah. Pengolaan sarana dan prasarana pembelajaran terdapat bebera tahapan ialah; perencanaan, pengadaan, penggunaan dan pemeliharaan sarana dan prasarana.

1. Perencanaan Sarana dan Prasarana 
Perencanaan sarana dan prasarana berawal dari mengidentifikasi sarana dan prasarana, memilah-milih sarana dan prasarana yang diperlukan, mencatat anggaran yang akan di beli dan dievaluasi. Dalam perencanaan sarana dan prasarana yang terlibat adalah yayasan, kepala sekolah, guru-guru dan staf TU. Selanjutnya pihak yayasan dan kepala sekolah mengadakan pertemuan dengan guru-guru beserta staf TU agar dapat mendiskusikan perencanaan kebutuhan sarana dan prasarana.

Pertama-tama para guru mengusulkan prosedur yang telah direncanakan, selanjutnya pihak yayasan dan kepala sekolah menampung usulan yang diajukan oleh guru-guru. Pihak yayasan, kepala sekolah dan guru-guru memilah dan memilih dengan seksama terkait usulan yang telah diajukan oleh guru-guru sebelumnya. Setelah dipilah dan dipilih kebutuhan sarana dan prasarana tersebut dicatat agar lebih jelas apa yang harus diutamakan dalam pengadaan dan disesuaikan dengan dana yang dimiliki. Sejalan dengan pendapat Muizzuddin (2019), perencanaan sarana dan prasarana memiliki beberapa tahapan ialah:

1. Melihat keperluan.

2. Mencatat barang-barang yang ada.

3. Memilah-milih sarana yang diperlukan.

4. Mempersiapkan dana.

5. Memberi tugas dan tanggungjawab untuk mempersiapkan sarana dan prasarana.

Dalam perencaranaan sarana dan prasarana memiliki tujuan ialah untuk memudahkan pihak sekolah dalam menentukan kebutuhan sarana dan prasarana, memudahkan proses pembelajaran, memudahkan pengelolaan keuangan, dan agar tersusunnya apa yang akan dilakukan atau yang akan dibeli. Adapun hambatan dalam perencanaan sarana dan prasarana yaitu dana atau anggaran yang tidak mencukupi sarana dan prasarana, prasarana yang kurang memadai ialah lahan yang tidak sesuai dengan apa yang telah ditetapkan oleh dinas pendidikan. Sedangkan menurut Minarti (2011), dalam perencanaan memiliki tujuan yaitu membantu proses belajar mengajar agar lebih efektif dan efisien. Jika salah dalam merencanakan sarana dan prasarana, maka akan membuat proses pembelajaran gagal dan kekeliruan dalam menentukan kebutuhan sarana dan prasarana untuk pembelajaran selanjutnya.

2. Pengadaan Sarana dan Prasarana Pembelajaran

Setelah melakukan proses perencanaan tahap kedua dalam pengelolaan ialah pengadaan sarana dan prasarana. Pengadaan sarana dan prasarana dilakukan dengan cara membeli atau menyewa sarana dan prasarana. Adapun pengadaan sarana yang dilakukan dengan membuat sendiri oleh para guru dengan memanfaatkan bahan yang ada.

Dalam pengadaan sarana dan prasarana melibatkan beberapa pihak yaitu kepala sekolah, guru-guru, staf TU dan petugas kebersihan. Peran kepala sekolah dalam pengadaan ialah pihak yang memutuskan dalam pengadaan sarana dan prasarana, peran guru dalam pengadaan ialah sebagai pihak yang membantu memberikan usulan kebutuhan sarana dan prasarana yang akan diadakan, peran TU dalam pengadaan ialah sebagai pihak yang mengawasi dan mencatat ketika sarana dan prasarana telah diadakan, dan petugas kebersihan berperan dalam membantu mengatur dengan menempatkan sarana sesuai dengan perintah kepala sekolah. Adapun hambatan dalam tahap pengadaan terdapat pada dana dan lahan.

Tujuan pengadaan ialah, agar proses pembelajaran menjadi efektif dan efisien, sebagai penunjang proses pembelajaran di sekolah, dan untuk menggantikan sarana yang rusak, hilang atau dihapuskan. Sejalan dengan pendapat Ihsan (2016), Pengadaan sarana dan prasarana ialah proses menyediakan sarana dan prasarana yang bisa dilakukan dengan cara pembelian, donasi, dan hibah. Diperkuat dengan pendapat menurut Fadillah (2019) yaitu pembelanjaan, menciptakan sendiri, pertolongan atau hadiah, penyewaan, peminjaman, memanfaatkan bahan yang tidak terpakai, bertukar-tukar, merenovasi.

Menurut Bafadal dalam Nurbaiti (2019), dalam pengadaan sarana dan prasarana terdapat beberapa prosedur pengadaan sarana dan prasarana sebagai berikut, dana yang diberikan pemerintah kepada pihak sekolah melakukan pembelian sarana dan prasarana, meminta partisipasi kepada lingkungan sekitar, mengadakan peralatan melalui peminjaman atau penyewaan, mengadakan peralatan sekolah melalui pertukaran benda yang dimiliki dengan benda lainya yang diperlukan sekolah. 
Lembaga PAUD yang diteliti oleh peneliti, menerima bantuan dari pemerintah seperti Bantuan Operasional Pendidikan yang sering dikenal sebagai BOP. Bantuan ini mengatur untuk barang yang diperlukan oleh sekolah dan guru untuk pendidikan anak. adapun pengadaaan yang dilakukan dengan cara membeli, membuat atau menyewa keberlangsungan pembelajaran.

3. Penggunaan Sarana dan Prasarana Pembelajaran

Tahap ke tiga dalam pengelolaan ialah penggsunaan sarana dan prasarana. Dalam penggunaan sarana dan prarana yang pertama yaitu, menganalisis kebutuhan dengan cara penggunaan sarana disesuaikan dengan tingkah usia anak dan tingkat perkembangan anak. Tahapan yang kedua penggunaan sarana disesuaikan dengan rppm atau kegiatan pembelajaran sehingga mempermudah proses pembelajaran. Tahapan terakhir yaitu pembuatan dan penggunaan media pembelajaran sesuai dengan perkembangan dan kebutuhan. Dalam prosedur pengunaan sarana dan prasarana di lembaga PAUD yang di teliti tidak terdapat aturan secara tertulis, sehingga para guru hanya memberitahu kepada murid untuk penggunaan sarana.

Terdapat pihak yang bertanggung jawab dan terlibat dalam penggunaan sarana dan prasarana ialah kepala sekolah dan para guru. Peran kepala sekolah ialah mengontrol secara langsung penggunaan sarana dan prasarana yang digunakan pada saat proses pembelajaran setiap satu hari dalam satu minggu, sedangkan peran guru dalam penggunaan sarana dan prasarana yaitu sebagai pembimbing dan mengawasi peserta didik dalam menggunakan sarana dan prasarana pembelajaran.

Sejalan dengan pendapat Firmansyah (2018), penggunaan ialah terlaksananya tujuan, kesesuaian antara media pembelajaraan dengan materi ajar, tersedianya sarana dan prasarana yang memadai, dan karakter peserta didik. Perlunya efektif dalam menggunakan sarana prasarana yaitu mempermudah tujuan pembelajaran kepada anak sehingga mudah dipahami dan menstimulasi perkembangan anak.

Tujuan dari penggunaan ialah memudahkan para guru dan peserta didik dalam proses belajar mengajar karena dengan penggunaan sarana dan prasarana dapat membantu menstimulasi perkembangan anak dan membuat peserta didik lebih kreatif. Adapun hambatan dalam penggunaan sarana dan prasarana. Sejalan dengan pendapat Menurut Watono (2008), pengadaan sarana dan prasarana memiliki tujuan ialah menunjang pembelajaran peserta didik agar pembelajaran berhasil dan optimal.

4. Pemeliharaan Sarana dan Prasarana Pembelajaran

Tahap terakhir dalam pengelolaan sarana dan prasarana ialah pemeliharaan sarana dan prasarana. Pemeliharaan dibagi menjadi tiga bagian yaitu pemeliharaan yang dilakukan secara terartur dan rutin dilaksanakan setiap hari oleh para guru dan peserta didik, seperti membereskan sarana yang telah digunakan. Pemeliharaan yang kedua ialah, pemeliharaan berskala yang dilakukan setiap satu tahun sekali oleh kepala sekolah, para guru dan TU. Seperti perbaikan atau pengecakan sarana dan prasarana (kursi, lemari, meja dan papan tulis). Selanjutnya pemeliharaan sarana dan prasarana yaitu pemeliharaan darurat yang tidak dapat ditentukan waktunya dan dilaksanakan oleh petugas khusus. Pemeliharaan darurat ini dilakukan jika ada suatu peristiwa yang tiba-tiba terjadi atau tidak diremcanakan seperti, mati lampu, bocor, kebanjiran hingga pihak sekolah memeritah pihak khusus untuk memperbaiki.

Adapun pihak yang bertanggung jawab dan terlibat ialah kepala sekolah, para guru dan TU.

Sebagaimana menurut Fatmawati (2019) pemeliharaan yaitu merawat, memelihara dan menyimpan barang sesuai dengan kelompok dan jenisnya, sehingga barang-baranag yang dipelihara tidak mudah rusak dan bisa bertahan lama. Penanggungjawab dalam pemeliharaan barang yaitu semua anggota sekolah yang terlibat. Sejalan dengan Bafadal dalam Mansur (2020), terdapat beberapa macam pemeliharaan sarana dan prasarana diantaranya,

1. Pemeriksaan pemeliharaan sarana dan prasarana

2. Pemeliharaan yang menghindari kerusakan

3. Pemeliharaan yang mempunyai tujuan untuk pembaharuan sarana dan prasarana yang bersifat perbaikan ringan atau berat.

Tujuan pemeliharaan sarana menurut Wayuningrum M.M (2000) dalam (Pamungkas, 2013) ialah, agar barang tidak mudah rusak dan bertahan lama, supaya barang tetap aman, agar JRPGP is licensed under Creative Commons Attribution- 
barang yang digunakan sesuai dengan kegunaan dan fungsi dan agar melatih tanggung jawab kepada yang menggunakan barang tersebut. Sejalan dengan tujuan dari lembaga PAUD, pemeliharaan ialah agar tidak mudah hilang, rusak dan agar guru serta murid menggunakan sarana dan prasarana dengan nyaman sehingga pembelajaran lebih efektif.

Adapun hambatan dalam pemeliharaan yaitu guru sering kesulitan dalam mengawasi peserta didik saat menggunakan sarana (alat permainan edukatif) dan buku cerita sehingga banyak permainan yang rusak dan buku cerita selalu berkurang ketika sesudah digunakan. Hambatan kedua yaitu dana, karena ketika ingin merawat sarana dan prasarana membutuhkan dana sehingga dana dibutuhkan untuk mempermudah pemeliharaan sarana dan prasarana. Sedangkan menurut Matin dan Nurhattati Fuad dalam Hidayah (2018), beberapa pemanfaatan dari kegiatan pemeliharaan sarana prasrana ialah

1. Ketika perlengkapan sarana dan prasarana dipelihara atau dirawat maka perlengkapan sarana tidak mudah rusak.

2. Jika sarana dan prasarana dipelihara dengan baik maka sarana dan prasaana akan bertahan lama dan tidak ada biaya untuk perbaikan dalam waktu singkat.

3. Jika pemeliharaan dirawat dengan baik, maka sarana dan prasarana lebih terkontrol untuk menghindari kerusakan.

4. Pemeliharaan sarana dan prasarana jika dirawat dengan baik, maka akan lebih bagus untuk dipandang.

5. Pemeliharaan yang baik akan menghasilkan pembelajaran yang efektif.

\section{Kesimpulan}

Berdasarkan pembahasan dalam penelitian ini, peneliti menyimpulkan beberapa hasil penelitian sebagai berikut:

1. Perencanaan

Perencanaan ialah sebuah proses yang harus dipikirkan untuk dilaksanakan di masa depan, agar tercapainya tujuan. Proses harus dipikirkan secara logis ialah suatu yang menunjang proses pembelajaran. Apabila dalam suatu proses perencanaan dilakukan dengan benar dan baik, maka tujuan pembelajaran akan tercapai dengan mudah.

Di lembaga PAUD yang diteliti telah menerapkan perencanaan sarana dan prasarana sesuai dengan teori perencanaan sarana dan prasarana.

2. Pengadaan

Pengadaan merupakan seluruh tindakan yang menyediakan kebutuhan benda untuk keberhasilan dalam pembelajaran. Dengan adanya pengadaan sarana dan prasana akan mempermudah guru memberikan stimulasi pada anak. Pengadaan sarana akan mudah terlaksana jika mempunyai dana untuk membeli atau menyewa barang, adapun dana yang bisa didapati yaitu melalui bantuan dari bantuan operasional sekolah (BOP), meminta sumbangan dari masyarakan melalui iuran sekolah dari pihak orang tua. Pengadaan sarana prasarana tidak harus selalu membeli tetapi bisa memanfaatkan bahanbahan bekas, menyewa, meminjam dan tukar menukar benda yang dimiliki.

Di lembaga PAUD yang diteliti telah menerapkan pengadaan sarana sesuai dengan teori, sedangkan untuk pengadaan prasarana belum sesuai dengan teori.

3. Penggunaan

Penggunaan ialah suatu pemanfaatan benda untuk membantu proses belajar mengajar, yang bertujuan agar pembelajaran lebih efektif dan efisien. Penggunaan sarana dan prasarana harus dipelihara agar sarana dan prasaran tidak mudah rusak. Penggunaan barang yang digunakan harus digunakan sebagai mestinya dan dipertanggungjawabkan oleh penggunanya.

Di lembaga PAUD yang diteliti telah menerapkan penggunaan sarana dan prasarana sudah sesuai dengan teori penggunaan sarana dan prasarana.

4. Pemeliharaan

Pemeliharaan ialah suatu aktivitas yang dilakukan dalam menjaga barang atau sarana dan prasarana agar tidak mudah rusak. Pemeliharaan sarana dan prasarana dikelompokan sesuai dengan barang-barang sehingga mudah untuk merawat sarana dan prasarana. 
Tahap pemeliharaan sarana dan prasarana yaitu dengan melakukan pemeriksaan barang yang sudah dikelompokan, dan melakukan pemelihaarn barang yang rusak ringan atau rusak berat.

Di lembaga PAUD yang diteliti telah menerapkan pemeliharaan sarana dan prasarana sudah sesuai dengan teori pemeliharaan sarana dan prasarana.

\section{Acknowledge}

Terimakasih yang sebesar-besarnya kepada segenap jajaran pihak fakultas yang terlibat dalam proses penelitian:

1. Bapak Enoh, Drs., M.Ag., selaku Dekan Fakultas Tarbiyah dan Keguruan Universitas Islam Bandung

2. Ibu Dr. Erhamwilda, Dra., M.Pd., selaku Ketua Program Studi PG-PAUD Fakultas Tarbiyah dan Keguruan Universitas Islam Bandung

3. Bapak Arif Hakim, M.Pd selaku dosen wali yang telah memberikan masukan dan motivasi untuk menyelesaikan skripsi ini.

4. Ibu Dr. Nan Rahminawati, M.Pd. selaku dosen pembimbing utama. Yang telah banyak meluangkan waktunya untuk memberikan arahan, bimbingan, dorongan serta ilmunya kepada penulis dalam penyusunan skripsi ini. Terimakasih saya ucapkan kepada ibu, semoga segala jasa yang telah iu berikan kepada penulis akan Allah ganti dengan curahan rahmat dan berkah dalam hidup ibu.

5. Ibu Dewi Mulyani, S.Pd.I., M.Pd.I selaku Pembimbing II yang telah banyak meluangkan waktunya dan dengan kesabaranya telah memberikan arahan, bimbingan, dorongan serta ilmunya kepada penulis untuk cepat menyelesaikan skripsi ini. Terimakasih ibu, semoga Allah ganti dengan curahan rahmat dan berkah dalam hidup ibu.

6. Ibu Nurul Afrianti, M. Pd., M.Si. Psi selaku dosen di Tarbiyah yang telah memberikan masukan dan motivasi untuk menyelesaikan skripsi ini.

7. Ibu Dr. Huriah Rachmah, M. Pd. selaku dosen di Tarbiyah yang telah memberikan masukan dan motivasi untuk menyelesaikan skripsi ini.

\section{Daftar Pustaka}

[1] Firmansyah, Tri, Achmad Supriyanto, dan Agus Timan. 2018. Efektivitas pesmanfaatan sarana dan prasarana dalam meningkatkan mutu layanan.

[2] Ihsan, Isnindya. 2016. Administrasi Sarana Dan Prasarana.

[3] Inawati, Tri. 2014. 53 Kondisi Sarana Dan Prasarana Di Taman Kanak-Kanak Yayasan Wanita Kereta Api Yogyakarta. Yogyakarta.

[4] Jannah, Miftahul. 2020. Pengelolaan Sarana dan Prasarana Pendidikan untuk Meningkatkan Proses Pembelajaran di SMKN 2 Bukittinggi.

[5] Minarti, Sri. 2011. Manajemen Sekolah Mengelola Lembaga Pendidikan Secara Mandiri.

[6] Muizzuddin, Muh. 2019. Manajemen Sarana dan Prasarana Pendidikan di Sekolah Menengah Pertama Al-Hikmah Benda Sirampog Brebes. 5(1): 14-37.

[7] Nur Hidayah, Siti. 2018. Manajemen Sarana dan Prasarana Pendidikan di Madrasah Tsanawiyah Negeri (MTsN) 2 Bandar Lampung.

[8] Rahmiga, Suci. 2019. Kurangnya Sarana Dan Prasarana Belajar Di Sekolah.

[9] Rahminawati, Nan. 2016. Manajemen Pendidikan.

[10] Suyadi, M.Pd.I. 2017. Manajemen PAUD TPA-KB-TK/RA. Yogyakarta. 